\title{
Reactivity of corneal and conjunctival epithelial cells to lipopolysaccharide (LPS) and/or irradiation with visible light in vitro
}

\author{
Roman Paduch ${ }^{1,2}$, Anna Matysik-Woźniak', Ryszard Maciejewski ${ }^{3}$, Anselm G. Jünemann ${ }^{4}$, \\ Robert Rejdak ${ }^{2,5}$ \\ ${ }^{1}$ Department of Virology and Immunology, Institute of Microbiology and Biotechnology, Maria Curie-Skłodowska University, Lublin, Poland \\ ${ }^{2}$ Department of General Ophthalmology, Medical University, Lublin, Poland \\ ${ }^{3}$ Department of Human Anatomy, Medical University, Lublin, Poland \\ ${ }^{4}$ Department of Ophthalmology, Rostock University Medical Center, Rostock, Germany \\ ${ }^{5}$ Medical Research Centre, Polish Academy of Science, Warsaw, Poland
}

\begin{abstract}
INTRODUCTION. Visible light and inflammation caused by bacterial endotoxins strongly influence direct cell interactions and modulate the expression of selected factors, such as nitric oxide (NO) and cyclooxygenase-2 (COX-2). The aim of the study is to establish whether exposition of corneal or conjunctival epithelial cells to visible light and/ or LPS may change their viability, direct cellular interactions and expression of NO and COX-2.

MATERIALS AND METHODS. In vitro cultured human corneal and conjunctival epithelial cells were used in the study. The following assays were performed: Neutral Red (NR) uptake, nitric oxide (NO) quantification by the Griess method, cytoskeletal F-actin organization by fluorescent staining, and COX-2 expression by immunofluorescence. RESULTS. LPS reduced the viability of the cells, especially conjunctival epithelial cells. All cell stimulation variants tested (visible light and/or LPS treatment) led to decreased nitric oxide (NO) production both by corneal and conjunctival epithelial cells. No changes in cytoskeletal F-actin filaments were observed after the cells had been treated with light or the endotoxin. LPS slightly increased COX-2 expression, but light had no, or a slightly reducing, effect on the level of this enzyme.

CONCLUSIONS. Visible light and/or bacterial endotoxin (LPS) may, depending on the local microenvironmental conditions, cooperate or interfere with each other's activity in inducing ocular surface inflammation.
\end{abstract}

KEY WORDS: Corneal epithelial cells, conjunctival epithelial cells, visible light irradiation, lipopolysaccharide, cyclooxygenase-2, nitric oxide

Ophthalmol J 2018; Vol. 3, No. 1, 1-7

\section{INTRODUCTION}

Visible light and inflammatory factors, such as bacterial lipopolysaccharide (LPS), have a strong influence not only on immune privilege within the eye but also on direct cell interactions and modulation of the expression of selected factors, including nitric oxide (NO) and cyclooxygenase-2 (COX-2) [1]. Bacteria are often a cause of serious ocular infections which lead to inflammation, making it difficult for the eye to maintain its normal corneal or conjunctival epithelial cell structure.

LPS, a bacterial endotoxin, has already been shown to induce pro-inflammatory cytokines (IL-6, IL- $1 \beta$, and TNF- $\alpha$ ) which interfere with ocular surface wound healing and may negatively affect vision [2]. Additionally, intermediate compounds of the 
COX-2 pathway of arachidonic acid metabolism (prostaglandins, prostacyclin, and thromboxane) are also involved in changes in the corneal and conjunctival epithelial lining, ultimately leading to reduced vision quality. The activity of all these compounds may be additionally enhanced when ocular surface cells are directly exposed to high-intensity visible light. As a consequence, oxidative reactions involving reactive oxygen and nitrogen species (RONS) may be induced which may limit the survival rate of ocular surface cells [3]. To find out what the consequences of such reactions are, we subjected human corneal and conjunctival epithelial cells in vitro to LPS and/or irradiation with visible, white light and then evaluated cellular morphology, and the expression of nitric oxide (NO) and the arachidonic acid pathway enzyme (COX-2), compounds which regulate the inflammatory state of the cellular microenvironment.

The goal of this work was to establish whether exposition of corneal or conjunctival epithelial cells to visible light and/or LPS changed the viability of these cells, direct cellular interactions, and NO and COX-2 expression.

\section{MATERIALS AND METHODS CELL LINES}

A normal human corneal epithelial cell line, 10.014 pRSV-T (ATCC No. CRL-11515), and a human conjunctival epithelial cell line, HC0597 (LGC Standards, UK), were used. The cells were cultured as monolayers in $25 \mathrm{~cm}^{2}$ culture flasks (Nunc ${ }^{\mathrm{TM}}$, Roskilde, Denmark) coated with PureCol ${ }^{\mathrm{TM}}$ ultrapure collagen (INAMED Biomaterials, Fremont, CA, USA) at $3.1 \mathrm{mg} / \mathrm{ml}$ concentration (about $12 \mu \mathrm{g} / \mathrm{cm}^{2}$ ). The cell lines were maintained in defined keratinocyte serum-free medium (K-SFM) $\left(\right.$ Gibco $^{\text {TM }}$, Paisley, UK) supplemented with $75 \mu \mathrm{g} / \mathrm{ml}$ endothelial cell growth factor (ECGF) (Sigma, St. Louis, MO, USA), $0.05 \mathrm{mg} / \mathrm{ml}$ bovine pituitary extract (BPE) (Gibco), $500 \mathrm{ng} / \mathrm{ml}$ hydrocortisone (Sigma), $0.0005 \mathrm{mg} / \mathrm{ml}$ bovine insulin (Gibco) and antibiotics $(100 \mathrm{U} / \mathrm{ml}$ penicillin, $100 \mu \mathrm{g} / \mathrm{ml}$ streptomycin) (Sigma, St Louis, MO, USA) at $37^{\circ} \mathrm{C}$ in a humidified atmosphere with $5 \% \mathrm{CO}_{2}$.

\section{EXPERIMENTAL DESIGN}

Cells were cultured in $35 \mathrm{~mm}$ Petri dishes (Nunc. ${ }^{\mathrm{TM}}$, Denmark). Cells were seeded at a density of $1 \times 10^{5}$ cells $/ \mathrm{mL}$. After $24 \mathrm{~h}$ of inoculation, the cells were stimulated:
- with lipopolysaccharide (LPS) from Escherichia coli, serotype 0111: B4 (Sigma) $(10 \mu \mathrm{g} / \mathrm{ml}$ for $2 \mathrm{~h}$ ) followed with $5 \mathrm{~min}$ exposure to the visible light $\left(120 \mu \mathrm{mol} / \mathrm{m}^{2 *} \mathrm{~s}\right)$ (Variant 1$)$

$-5 \mathrm{~min}$ exposure to the visible light $\left(120 \mu \mathrm{mol} / \mathrm{m}^{2 *}\right.$ s) followed with lipopolysaccharide (LPS) from Escherichia coli, serotype 0111:B4 (Sigma) $(10 \mu \mathrm{g} / \mathrm{ml}$ for $2 \mathrm{~h})$ (Variant 2)

- with lipopolysaccharide (LPS) from Escherichia coli, serotype 0111: B4 (Sigma) $(10 \mu \mathrm{g} / \mathrm{mL}$ for 2 h) (Variant 3)

- $5 \mathrm{~min}$ exposure to the visible light $\left(120 \mu \mathrm{mol} / \mathrm{m}^{2}\right.$ * s) (Variant 4)

After cells stimulation with appropriate factors or their combination, the culture medium was changed for a new one and cells were cultivated further for $24 \mathrm{~h}$.

\section{NEUTRAL RED (NR) CELL CYTOTOXICITY ASSAY}

The Neutral Red (NR) cell cytotoxicity assay is based on the uptake and lysosomal accumulation of the vital dye neutral red. Dead or damaged cells do not take up the dye. Cells were grown in 96-well plates in $100 \mu \mathrm{l}$ of K-SFM with supplements and in different culture conditions (with/without LPS pre-incubation and light exposure). Subsequently, the medium was discarded and $0.4 \%$ NR (Sigma) solution medium was added to each well. The plate was incubated for $3 \mathrm{~h}$ at $37^{\circ} \mathrm{C}$ in a humidified $5 \% \mathrm{CO}_{2} / 95 \%$ air incubator. After incubation, the dye-containing medium was removed, cells were fixed with $1 \% \mathrm{CaCl}_{2}$ in $4 \%$ paraformaldehyde, and thereafter the incorporated dye was solubilized using $1 \%$ acetic acetate in a $50 \%$ ethanol solution $(100 \mu \mathrm{l})$. The plates were gently shaken for $20 \mathrm{~min}$ at room temperature and the extracted dye absorbance was measured spectrophotometricaly at $540 \mathrm{~nm}$.

\section{NITRIC OXIDE (NO) MEASUREMENT}

Nitrate, a stable end product of NO, was determined in culture supernatants using a spectrophotometric method based on the Griess reaction. Briefly, $100 \mathrm{ml}$ of the supernatant collected after $24 \mathrm{~h}$ incubation was plated in 96-well flat-bottomed plates in triplicate and incubated for $10 \mathrm{~min}$ with $100 \mathrm{ml}$ of the Griess reagent (1\% sulfanilamide/0.1\% $\mathrm{N}$-(1-naphthyl) ethylenediamine dihydrochloride) (Sigma) in 3\% $\mathrm{H}_{3} \mathrm{PO}_{4}$ (POCH Gliwice, Poland) at room temperature. The optical density was measured at $550 \mathrm{~nm}$ using a microplate reader (Molecular Devices Corp., Emax, Menlo Park, CA, USA). A stan- 
dard curve was performed using $0.5-25 \mu \mathrm{M}$ sodium nitrite $\left(\mathrm{NaNO}_{2}\right)$ for calibration.

\section{CELLULAR CYTOSKELETON F-ACTIN ORGANIZATION ANALYSIS}

Cells were incubated in 4-well Lab-Tek chamber slides (Nunc) filled with $1 \mathrm{~mL}$ of culture medium. The cells were exposed to factors in the variants described above. As controls, untreated cells were accepted. Cells were rinsed with K-SFM medium and exposed to paraformaldehyde $(10 \%$, $\mathrm{v} / \mathrm{v}$ ) solution for $20 \mathrm{~min}$, rinsed three times in phosphate-buffered saline (PBS), exposed to Triton X-100 $(0.2 \%, \mathrm{v} / \mathrm{v})($ Sigma) solution for $5 \mathrm{~min}$ and rinsed three times with PBS. $0.5 \mathrm{ml}$ PBS containing tetramethyl-rhodamine-isothiocyanatephalloidin (TRITC-phalloidin, $1 \mu \mathrm{g} / \mathrm{mL}$, Sigma) was added to each well and incubated in the dark at $37^{\circ} \mathrm{C} 15 \% \mathrm{CO}_{2}$ for $30 \mathrm{~min}$. Cell examination was conducted under a fluorescent microscope (Olympus, BX51). Quantitative analysis of fluorescent images was performed using an AnalySIS imaging software system.

\section{INDIRECT IMIMUNOFLUORESCENCE}

Cells were inoculated for $24 \mathrm{~h}$ in K-SFM medium in 4-well Lab-Tek glass slides at a density of $1 \times 10^{5}$ cells $/ \mathrm{mL}$. Thereafter, the cells were stimulated with LPS or visible light and their combination. After renewal of the culture medium, further incubation was performed for another $24 \mathrm{~h}$. Next, the cells were washed twice with PBS with $\mathrm{Ca}^{2+}$ and $\mathrm{Mg}^{2+}$ ions, fixed in $4 \%$ paraformaldehyde for 10 min, washed three times with PBS, permeabilized with $0.1 \%$ Triton X-100 for 7 min, washed three times with PBS and blocked with 7.5\% FCS for $1 \mathrm{~h}$ at room temperature. The cells were then incubated overnight at $4^{\circ} \mathrm{C}$ with primary goat anti-COX-2 IgG polyclonal antibody (Santa Cruz Biotechnology, Inc.). After washing twice with PBS, the cells were incubated with secondary fluorescein isothiocyanate (FITC)-conjugated donkey anti-goat IgG (Santa Cruz Biotechnology, Inc.). Then they were examined with a Nikon Eclipse Ni microscope equipped with a Nikon digital sight DS-QiMc camera (Nikon) at an excitation wavelength of $480 \mathrm{~nm}$ and an emission wavelength of $530 \mathrm{~nm}$.

\section{STATISTICAL ANALYSIS}

The results are presented as means \pm SD of three independent experiments $(n=3)$. The data were an- alyzed using one-way analysis of variance ANOVA followed by Dunnett's multiple comparison posthoc test. Differences of $\mathrm{p} \leq 0.05$ were considered significant.

\section{RESULTS}

Viability of cells, measured by the Neutral Red (NR) uptake assay, revealed that variants 2 and 4 of cell stimulation had no influence on the stability of the cellular membranes of the corneal and conjunctival epithelium. Stimulation variants 1 and 3 significantly decreased the viability of conjunctival epithelial cells, having no impact on the corneal epithelium. Cell viability dropped by about $12 \%$ and $7 \%$ in comparison to the untreated control, respectively (Fig. 1).

All cell stimulation experiments led to decreased nitric oxide (NO) production by both corneal and conjunctival epithelial cells. Conjunctival epithelial cells produced lower amounts of NO than corneal epithelium. Substantial falls in NO production were observed for both kinds of ocular cells after they were stimulated with the factors used in variant 3 of the experiment. In these conditions, corneal epithelial cells released 5.1-times, and conjunctival cells 10.5-times, less NO than the untreated control (Fig. 2).

The stimulatory variants tested had no influence on the organization of F-actin filaments of the cellular cytoskeleton, except for variant 3. When stimulated with LPS, cells tended to weaken their intercellular interactions, which was particularly conspicuous in the case of the conjunctival epithelium (Fig. 3).

COX-2, measured by immunofluorescence, was expressed in the cytoplasm of both corneal and conjunctival epithelial cells, with the latter expressing higher amounts of this factor. Variant 3 of stimulation increased COX-2 expression in the ocular cells tested, particularly in the conjunctival epithelium (Fig. 3).

\section{DISCUSSION}

Visible light can exert a biostimulating effect on ocular epithelial cells, but it can also induce damage to these cells. Its effect depends both on the intensity of the light and additional factors such as inflammation or infection of the eye. In our study, we tried to establish whether exposure of corneal or conjunctival epithelial cells to visible light (instantaneous 


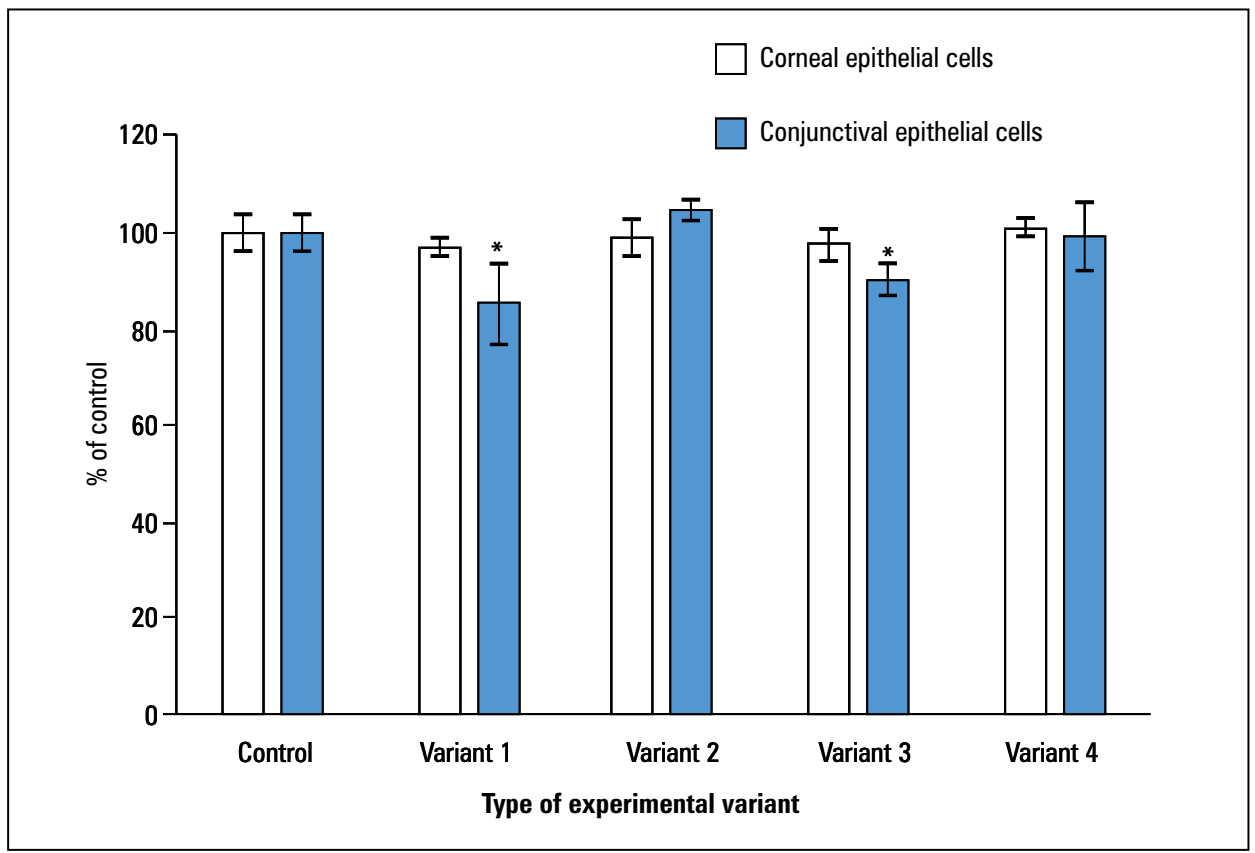

FIGURE 1. Neutral Red (NR) uptake assay performed after $24 \mathrm{~h}$ of corneal and conjunctival epithelial cells culture followed by their stimulation with lipopolysaccharide (LPS) from Escherichia coli, serotype 0111:B4 (Sigma) (10 $\mu \mathrm{g} / \mathrm{ml}$ for $2 \mathrm{~h}$ ) and/or 5 min exposure to the visible light $\left(120 \mu \mathrm{mol} / \mathrm{m}^{2 *} \mathrm{~s}\right)$. Variants description revealed in materials and methods section.

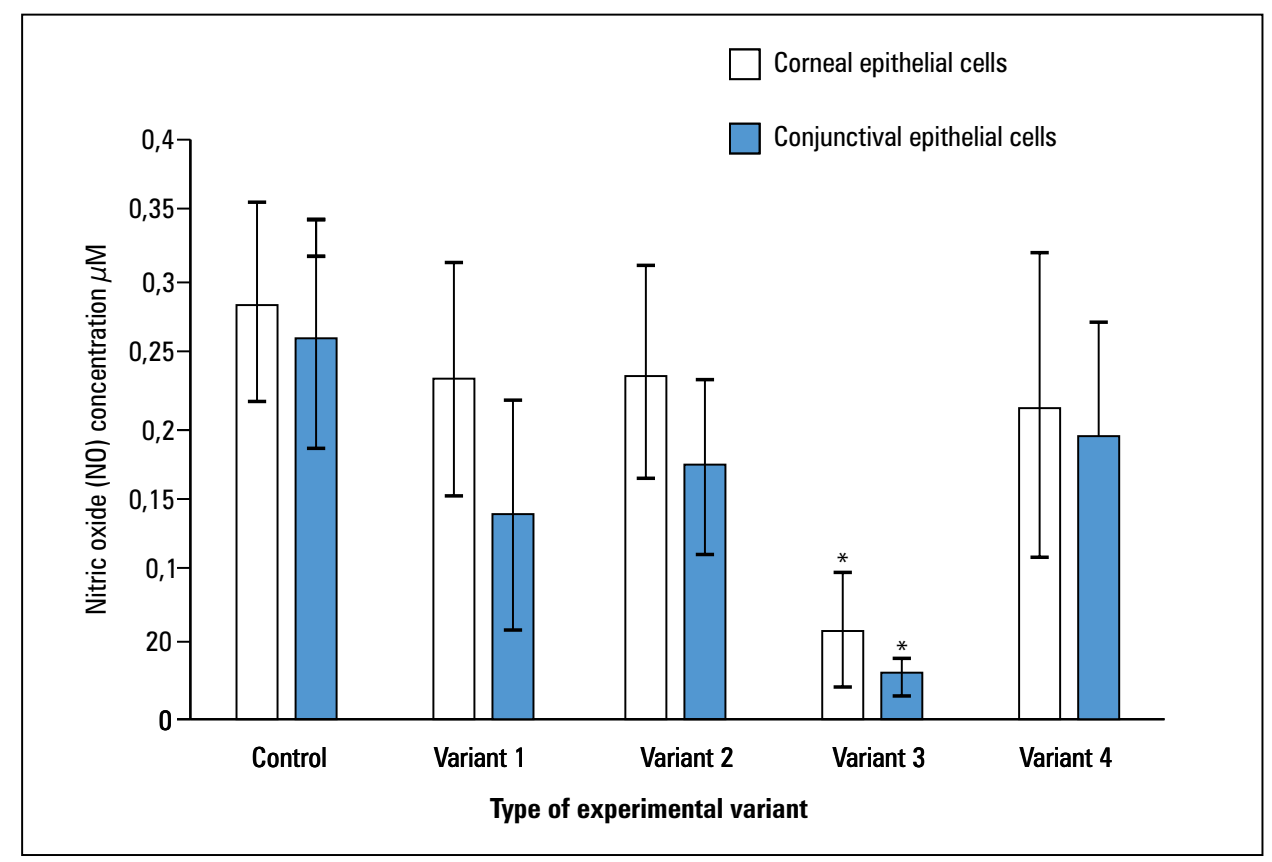

FIGURE 2. Nitric oxide (NO) production by corneal and conjunctival epithelial cells after their stimulation with lipopolysaccharide (LPS) from Escherichia coli, serotype 0111:B4 (Sigma) $\left(10 \mu \mathrm{g} / \mathrm{ml}\right.$ for $2 \mathrm{~h}$ ) and/or $5 \mathrm{~min}$ exposure to the visible light $\left(120 \mu \mathrm{mol} / \mathrm{m}^{2 *} \mathrm{~s}\right)$ and further $24 \mathrm{~h}$ of culture. Variants description revealed in materials and methods section

photon flux density of $\left.120 \mu \mathrm{mol} / \mathrm{m}^{2} * \mathrm{~s}\right)$ and/or LPS $(10 \mu \mathrm{g} / \mathrm{ml}$ for $2 \mathrm{~h})$ changed the viability of these cells and the oxidative reactions based on $\mathrm{NO}$ and COX-2 expression. Induction of the cells with
LPS decreased their viability, which dropped further slightly, especially for conjunctival epithelial cells, after they were exposed to light. This effect may have been linked with the apoptosis-inducing activ- 


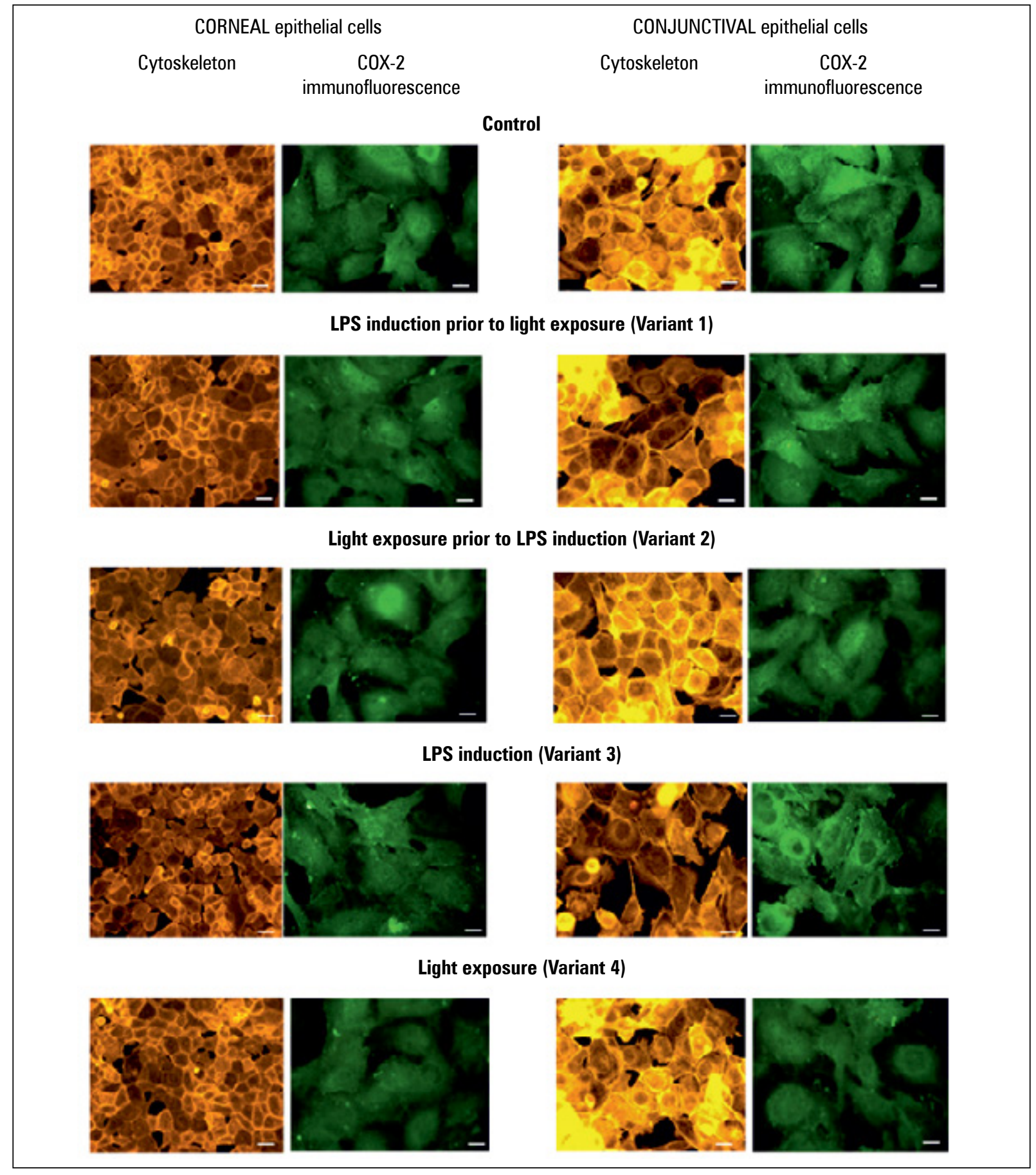

FIGURE 3. Cellular cytoskeleton F-actin organization analysis of corneal and conjunctival epithelial cells after their stimulation with lipopolysaccharide (LPS) from Escherichia coli, serotype 0111:B4 (Sigma) $(10 \mu \mathrm{g} / \mathrm{mL}$ for $2 \mathrm{~h}$ ) and/or $5 \mathrm{~min}$ exposure to the visible light (120 $\mu \mathrm{mol} / \mathrm{m}^{2 *} \mathrm{~s}$ ) and further $24 \mathrm{~h}$ of culture. Magnification $100 \mathrm{x}$. Bar $=100 \mu \mathrm{m}$.

Immunofluorescence staining for COX-2 expression in corneal and conjunctival epithelial cells after $2 \mathrm{~h}$ treatment with LPS E. coli (10 $\mu \mathrm{g} /$ $\mathrm{mL}$ ) or/and $5 \mathrm{~min}$ irradiation with visible light $\left(120 \mu \mathrm{mol} / \mathrm{m}^{2 *} \mathrm{~s}\right)$. After medium was changed the cell culture was conducted for further 24 h. Magnification 200x. Bar $=20 \mu \mathrm{m}$

ity of cytokines produced via the toll-like receptor (TLR4/MD2 complex) signaling pathway after induction of inflammation by LPS [2]. Moreover, LPS induction followed by light irradiation may have affected the cytoskeletal proteins or the stability of the plasma membrane-cytoskeleton complex as well as interfering with repair mechanisms. All this/All those events may have led to cumulative damage 
of protective factors and processes in the cells and, ultimately, apoptotic cell death [4].

An interesting observation, however, was that a reverse sequence of irradiation followed by LPS induction had a protective effect on the cells. No cell destruction was observed when the two factors were used in this order. It can be supposed that visible light, to a certain extent, protected the cells from the adverse effects of inflammation caused by the presence of the bacterial endotoxin on the ocular surface. This supposition seems to be confirmed by the findings of Ohta et al. (2007), who suggested that nitric oxide (NO) generated upon induction of cells with LPS could increase their survival rate after irradiation. An observation that further supports this claim is that, in the same study, LPS and irradiation did not increase cytokine production by cells [3]. The protective role of NO is, however, merely a speculation and only one side of the issue, because NO, as a factor with a dual nature, is often observed to induce both cytoprotective and cytotoxic effects. Therefore, NO may protect cells or express a weak cell damaging effect independently of irradiation or conversely at higher concentrations it may be closely linked with damage of cells through reactive nitrogen species after cells irradiation. Nevertheless, our results indicate that the order in which the stimuli are applied also plays an important role in the processes of cell protection versus cell destruction.

Given the results we obtained in the first part of the study regarding the presumably leading role of NO in the proper functioning of the cells of the ocular surface, we wanted to find out, in further experiments, whether visible light and/or LPS changed the production of this radical and the expression of the COX-2 enzyme. We found that independently of the experimental variant used, cells treated with light and/or LPS produced lower levels of NO compared to the untreated control. This is in agreement with the observations of Erdinest et al. (2015), who found no significant elevation in NO secretion by human corneal and conjunctival epithelial cells during LPS-induced inflammation. This finding may suggest that LPS alone does not induce NOS-2 expression and, consequently, the level of the radical does not increase. This is another argument supporting the hypothesis that NO, at a relatively low level, may act as a cell survival promoting factor as well as a compound normalizing ocular surface healing processes [5]. However, in our study, we observed that visible light irradiation always in- creased NO production by ocular surface cells as compared to cells treated with LPS alone. LPS may, therefore, be viewed as a mediator in the delayed response to inflammation caused by visible light or UV radiation [6]. At higher concentrations, NO may induce cell damage and accelerate the activity of the arachidonic acid COX-2 enzyme, leading to an enhanced secretion of prostaglandins and all the effects associated with increased inflammation [7]. In our study, LPS increased the expression of COX2 , while visible light irradiation had no significant influence on the secretion of this enzyme in corneal and conjunctival cells. COX-2 is involved in the production of prostaglandin $\mathrm{E}_{2}\left(\mathrm{PGE}_{2}\right)$, which, at increased levels, together with pro-inflammatory cytokines may trigger the development of ocular surface diseases. This enzyme and cytokines such as IL- $1 \beta$, IL-6, IL- 8 , and TNF- $\alpha$ regulate each other's expression and signaling cascades of activation, in this way mutually reinforcing the locally developing inflammation $[8,9]$. Our observations are in good agreement with the results obtained by Choi et al. (2012), who demonstrated increased COX-2 expression in gingival fibroblasts treated with LPS [10]. Similar findings were obtained by Anfuso et al. (2017) for rabbit corneal epithelial cells [11]. Taking into account the changes in NO and COX-2 levels caused by induction of the ocular surface cells with LPS, we may suppose that these compounds are not necessarily involved in triggering inflammation. Their effect strongly depends on the local concentration of $\mathrm{NO}$ and the level of COX-2 induced by LPS. It may be supposed that, in our experimental conditions, ocular surface inflammation was mainly based on the activity of prostaglandins and cytokines rather than the toxic or radical activity of NO.

On the other hand, visible light irradiation decreased or had no influence on COX-2 expression in corneal and conjunctival epithelial cells. Other authors confirm this observation, indicating that irradiation with specific light wavelengths or during radiotherapy decreases the expression of COX-2 and $\mathrm{PGE}_{2}$ in normal and tumor tissues, ultimately limiting the development of local inflammation $[10,12]$.

To conclude, we believe that, depending on local, microenvironmental conditions, visible light and/or the bacterial endotoxin (LPS) may cooperate or limit each other's activity in inducing ocular surface inflammation. We suppose that nitric oxide (NO) may play a significant role in this process. Depending on its concentration, NO may adversely 
affect the structure and function of eye surface cells after irradiation or bacterial infection, or it can play a beneficial physiological role as an agent that controls and protects the proper functioning of corneal and conjunctival epithelial cells.

\section{CONFLICT OF INTEREST}

The authors report no conflicts of interest. The authors alone are responsible for the content and writing of the paper.

\section{REFERENCES}

1. Hajrasouliha AR, Kaplan HJ. Light and ocular immunity. Curr Opin Allergy Clin Immunol. 2012; 12(5): 504-509, doi: 10.1097/ACI.0b013e$328357 \mathrm{~d} 3 \mathrm{a} 4$, indexed in Pubmed: 22892711.

2. Liang $H$, Brignole-Baudouin $F$, Labbé $A$, et al. LPS-stimulated inflammation and apoptosis in corneal injury models. Mol Vis. 2007; 13: 1169-1180, indexed in Pubmed: 17679944.

3. Ohta $S$, Matsuda $S$, Gunji $M$, et al. The role of nitric oxide in radiation damage. Biol Pharm Bull. 2007; 30(6): 1102-1107, doi: 10.1248/ bpb.30.1102, indexed in Pubmed: 17541161.

4. Weinreb 0, Dovrat A, Dunia I, et al. UV-A-related alterations of young and adult lens water-insoluble $\alpha$-crystallin, plasma membranous and cytoskeletal proteins. European Journal of Biochemistry. 2001; 268(3): 536-543, doi: 10.1046/j.1432-1327.2001.01885.x, indexed in Pubmed: 11168392.
5. Erdinest N, Shohat N, Moallem E, et al. Nitric oxide secretion in human conjunctival fibroblasts is inhibited by alpha linolenic acid. J Inflamm (Lond). 2015; 12: 59, doi: 10.1186/s12950-015-0104-1, indexed in Pubmed: 26500455.

6. Seo SJ, Choi HG, Chung HJ, et al. Time course of expression of mRNA of inducible nitric oxide synthase and generation of nitric oxide by ultraviolet B in keratinocyte cell lines. Br J Dermatol. 2002; 147(4): 655-662, doi: 10.1046/j.1365-2133.2002.04849.x, indexed in Pubmed: 12366409.

7. Wang $Z Y$, Håkanson R. Role of nitric oxide (NO) in ocular inflammation. Br J Pharmacol. 1995; 116(5): 2447-2450, doi: 10.1111/j.14765381.1995.tb15094.x, indexed in Pubmed: 8581283.

8. Cruz R, Quintana-Hau JD, González JR, et al. Effects of an ophthalmic formulation of meloxicam on COX-2 expression, PGE2 release, and cytokine expression in a model of acute ocular inflammation. $\mathrm{Br} \mathrm{J}$ Ophthalmol. 2008; 92(1): 120-125, doi: 10.1136/bjo.2007.125179, indexed in Pubmed: 17962388.

9. Chiang CC, Cheng YW, Lin CL, et al. Cyclooxygenase 2 expression in pterygium. Mol Vis. 2007; 13: 635-638, indexed in Pubmed: 17515883.

10. Choi H, Lim W, Kim I, et al. Inflammatory cytokines are suppressed by light-emitting diode irradiation of P. gingivalis LPS-treated human gingival fibroblasts: inflammatory cytokine changes by LED irradiation. Lasers Med Sci. 2012; 27(2): 459-467, doi: 10.1007/s10103-0110971-5, indexed in Pubmed: 21814735.

11. Anfuso CD, Olivieri M, Fidilio A, et al. Gabapentin Attenuates Ocular Inflammation: and Studies. Front Pharmacol. 2017; 8: 173, doi: 10.3389/ fphar.2017.00173, indexed in Pubmed: 28420991.

12. Ozdal PC, Callejo $S$, Caissie AL, et al. Cyclooxygenase-2 expression in human irradiated uveal melanomas. Int Ophthalmol. 2008; 28(1): 1-6, doi: 10.1007/s10792-007-9096-z, indexed in Pubmed: 17603773. 